\title{
Commercially Available Materials Selection in Sustainable Design: An Integrated Multi-Attribute Decision Making Approach
}

\author{
Rui Zhao ${ }^{1}$, Han $\mathrm{Su}^{1}{ }^{1}$, Xiaolang Chen ${ }^{2}$ and Yanni $\mathrm{Yu}^{3, *}$ \\ Received: 18 October 2015; Accepted: 11 January 2016; Published: 16 January 2016 \\ Academic Editors: Bing Wang, Ning Zhang and Marc A. Rosen \\ 1 State-Province Joint Engineering Research Lab in Geospatial Information Technology for High Speed \\ Railway Safety, Southwest Jiaotong University, Chengdu 611756, China; ruizhaoswjtu@hotmail.com (R.Z.); \\ tygt12@163.com (H.S.) \\ 2 Key Laboratory of Advanced Materials Technology Ministry of Education, School of Materials Science and \\ Engineering, Southwest Jiaotong University, Chengdu 610031, China; chenx1612@sina.com \\ 3 Institute of Resource, Environment and Sustainable Development (IRESD), Jinan University, \\ Guangzhou 510632, China \\ * Correspondence: yayabaobei@naver.com; Tel.: +86-791-8381-0553
}

\begin{abstract}
This paper presents an integrated multi-attribute decision-making (MADM) approach to aid selection of commercially available materials in the context of sustainable design. The MADM couples grey relational analysis (GRA) with an analytic hierarchy process (AHP) to rank alternative materials in terms of their economic, environmental, and social performance. AHP is used to determine the corresponding weighting values for the selected indicators. In addition, a case example is used to verify the proposed MADM method and demonstrate its practical application. Three alternative polymer materials, i.e., poly(vinyl chloride) (PVC), polypropylene (PP), and polyethylene (PE), are examined to determine their sustainability for plastic pipe design. The associated MADM result and the limitations of the approach are discussed to lay the foundation for further improvement.
\end{abstract}

Keywords: materials selection; multi-attribute decision-making; sustainable design; analytic hierarchy process; grey relational analysis

\section{Introduction}

In recent years, low-carbon development has been gradually entering product life-cycle management to combat climate change under umbrella terms such as "green design", "eco-design", "environmentally conscious design" or "design for environment" [1-3]. Green design, also called sustainable design and environmental design is a philosophy which seeks to improve design performance by incorporating environmental, health, and safety attributes into product design decisions, thus reducing the entire life-cycle impact [4-8].

Materials selection plays a crucial role in product design [9]. A number of studies have given emphasis on material selection by "design-oriented", i.e., by functional demand of a product . For example, Chauhan and Vaish (2012) applied the VlseKriterijumska Optimizacija I Kompromisno Resenje (VIKOR) and the technique for order preference by similarity to ideal solution (TOPSIS) methods to soft and hard magnetic materials classification and selection [10]. Khare et al. (2012) proposed a multi-objective optimization model to identify the most appropriate phase change materials (PCMs) for latent heat storage design [11]. Similarly, Mansor et al. (2013) employed the multi-objective optimization methodology for materials selection in design of an automotive brake 
lever [12]. O'Connor et al. (2016) proposed materials selection criteria for a new skin-wearable organic solar cell design based on its mechanical compliance [13].

Some studies have focused on materials selection by market demand. For instance, Prasad and Chakraborty (2013) used a quality function deployment (QFD)-based approach to select the suitable materials by integrating the voice of the customers with product functionality [14]. Tamani et al. (2015) designed a multi-criteria decision support system for fresh food packaging, in which consumers' preferences were considered [15]. Kwong et al. (2016) employed an artificial intelligence (AI) based methodology for materials selection in design of electric iron, by which the factors of affective design, engineering, and marketing issues were taken into account [16].

Materials selection is also oriented by cost consideration. Rahman et al. (2012) developed a decision support system for roofing materials selection, in which the conceptual cost for the roof element was assessed in the early stage of building design [17]. Kumar et al. (2014) used the entropy with TOPSIS method to evaluate the optimum material for exhaust manifold design, in which cost was taken as an important criterion [18]. IIg et al. (2016) calculated life cycle cost of several high-performance materials (HPM) in infrastructure. Discount rate, expected service life and external costs were identified as the major factors in affecting the performances of materials [19].

However, most of them have not taken environmental management as a key aspect of materials selection in product design. With raw materials being extracted at an increasing rate, product design is affected by a growing public attention to sustainable development [20-23]. In this context, selection of materials should follow the principles of green design to mitigate adverse impact on both environmental and human health, to enhance product quality and to minimize toxicity of materials [23,24].

In order to provide better, safer, and more sustainable products for publics, it is important to predefine the material in the initial period of product design. Materials for further industrial manufacture that are more environmentally friendly, e.g., minimizing environmental impact and maximizing economic and social benefits, should be identified. A number of studies have taken the life cycle assessment into materials selection as an environmental impact assessment [25-29]. For instance, Ribeiro et al. (2013) assessed the life-cycle-based performance of injection-molded samples made of four commercial biodegradable polymers [30]. Hosseinijou et al. (2014) proposed social-life cycle assessment (S-LCA) for building materials selection, in which three stages as pre-building, building and post-building were taken into account [31]. Van der Velden et al. (2015) employed LCA approach for materials selection to promote the sustainability of smart textile garment, in which eco-cost of resource depletion, carbon footprint, human health were taken as the typical indicators [32]. However, life cycle assessment (LCA) is difficult for engineering designers to implement in real applications, due to the predicament of required data acquistion, data quality control, product system boundary division etc. [33,34]. In this context, there is a need for an approach that is simple to use.

This study contributes to the literature by developing a computational method for the use of engineers or designers to aid in the selection of commercially available materials by taking some typical indicators into account, e.g., economic, environmental, and social performance, thus promoting green design and improving product quality.

The selection of materials may be influenced by many factors, such as product function, cost, environment, or consumer satisfaction $[35,36]$. Because of conflicting or competing objectives, such as economic cost and environmental restrictions, the selection of materials for engineering design may be treated as a multi-criteria decision-making problem (MCDM) [37-39]. MCDM is often divided into two categories, the multiple-objective decision-making (MODM) and multiple-attribute decision-making (MADM) methods [40]. The former is an optimization technique based on prioritized functional relationships such as the maximization of sales profit or the minimization of cost. By contrast, the latter one mainly focuses on the comparison and, subsequently the ranking of alternatives based on attribute weighting or user defined data [10,41,42]. 
In real process of materials selection, a number of variables should be taken into account. However, only several variables can be involved when using the MODM techniques for materials selection $[43,44]$. MADM methods such as analytic hierarchy process (AHP), TOPSIS, VIKOR, and Grey Relational Analysis (GRA) are able to rank material alternatives and help designers determine the best material, defined as the highest degree of satisfaction [45-49].

The MADM methodology for materials selection in our study provides an important decision-making tool when confronted with a number of closely differing materials for diversified needs. This study further integrates two common MADM methodologies: AHP, used for weighting of selected indicators, and GRA for further comparison. GRA is based on the measurement of the degrees of similarity or difference among several numerical sequences, which is used to identify the relative influences of the sequences for comparison with a predetermined reference sequence [50,51]. The GRA gives the preferential order of various investigated objects in terms of a certain performance index. However, the relative importance of the various indices is difficult to determine, e.g., some of the indicators may be conflicting [52]. In comparison, the analytic hierarchy process (AHP) is a classic method to fill this gap, as it is used to assess the relative importance among indices. Generally, the purpose of AHP is to decompose a complex decision issue into a variety of hierarchies and factors, which is a typical subjective weighting method based upon the judgment and synthesis of decision makers [53]. An ordered hierarchical decision is thus composed of a dominance relationship in which the weights among different indicators are determined through pairwise comparison [54]. Therefore, integration of the two methods can give rise to a maximization of their advantages, which also facilitates the multi-attributive decision-making of a complex system.

This study further gives preferences of selection between similar materials (with similar physical and chemical properties) to examine their performance. A case example is used to verify the proposed MADM method and demonstrate its practical application. Three alternative polymer materials, i.e., poly(vinyl chloride) (PVC), polypropylene (PP), and polyethylene (PE), are examined to determine their sustainability for plastic pipe design. It is further expected that this integrated approach may help manufacturers to implement sustainable design, and thus to enhance product sustainability.

\section{Integrated MADM Approach for Materials Selection}

As environmental resources are increasingly depleted, products are gradually being developed with less impact to the environment, thus moving towards "sustainability." In this context, this study has identified a number of typical indicators to represent product sustainability as a basis for materials selection, based upon the basic principles and guidelines of sustainable design to construct a decision matrix, shown in Table $1[2,24,55,56]$.

Table 1. Selected indicators for material selection.

\begin{tabular}{cc}
\hline Attributes & Indicators \\
\hline \multirow{3}{*}{ Economic } & Direct cost \\
& Manufacturing cost \\
& Manufacture defects \\
& Sales profit \\
\hline Environmental & Energy consumption \\
& Health risk \\
& Waste-gas production \\
& Wastewater production \\
& Solid waste production \\
\hline Social & Product satisfaction \\
& Material recyclability \\
& Material reusability \\
& Use of recycled Materials \\
\hline
\end{tabular}


For any manufacturer, there are triple bottom lines (TBL) to run a sustainable business from bottom to top, i.e., as basic market demand, alternative materials and energy for production, and pursuing societal value for environmental protection [57-62]. The manufacturer is primarily driven by profit, as economic issues play a dominant role in business operations [61,63-65]. Thus, four economic indicators are taken into consideration including direct cost, manufacturing cost, manufacture defects and sales profit. With the conflicts between economic growth and environmental protection being paid more and more attention, the most preferable strategy for encompassing sustainable development is to implement cleaner production [66,67].The mitigation of adverse impact of products on environment and human health can be achieved partly by the careful selection of materials. Thus, five indicators are proposed to represent the product environmental performances: energy consumption, health risk, waste-gas production, wastewater production, and solid waste production $[68,69]$.

The social attributes proposed in this study is from a perspective of corporate social responsibility (CSR), in order to extend manufacturer's responsibility through the improvement of product sustainability, such as improving product life cycle (including reusability and recyclability), reforming the quality of products, etc., to provide better, safer and sustainable products for public consumption [70-72]. Proposed by McDonough and Brauggart (2002), all materials can be classified into two categories in a closed-loop social system: "technical" or "biological" nutrients [73]. The technical nutrients are those non-toxic and non-harmful materials, which can be reused directly in continuous cycles without losing their integrity or quality, and parts of which can be recycled for their quality and functionality, e.g., the cola bottle [74]. In this context, "material reusability", "material recyclability" and "use of recycled materials" are selected to reflect the manufacturer's social responsibility for product waste prevention.

The use of these evaluation indicators, by taking economic, environmental and social dimensions into account, is expected to help improve and monitor process of product design [75,76]. The proposed MADM approach combines GRA with AHP to rank alternative materials by their economic, environmental, and social performance. AHP is used to determine the weights of the selected indicators. GRA is then used to develop an evaluation approach to aid material selection. The detailed computational approach is presented below.

\subsection{Weighting by AHP}

Generally, the weighting approach can be divided into two categories: objective and subjective weighting determination [77]. The former obtains the weights derived from the collected data corresponding to each indicator. However, the different indicators may result in weighting variation, and the actual importance of indicators could be conflicted [78]. The latter is mainly dependent upon the decision maker's preferences regarding the attributes, e.g., AHP is a subjective decision-making tool, which is widely used for weighting determination [79]. Generally speaking, there are three steps to the AHP calculation [80]:

(1) decompose an issue into a hierarchy system: the above attributes are classified into three categories: economic, environmental, and social,

(2) establish a pairwise comparison matrix to compare a set of $n$ attributes in relative importance:

$$
A=\left[\begin{array}{ccccc}
a_{11} & \cdots & a_{1 j} & \cdots & a_{1 n} \\
\vdots & & \vdots & & \vdots \\
a_{i 1} & \cdots & a_{i j} & \cdots & a_{i n} \\
\vdots & & \vdots & & \vdots \\
a_{n 1} & \cdots & a_{n j} & \cdots & a_{n n}
\end{array}\right]
$$

where $a_{1}, a_{2}, \ldots, a_{n}$, denote various attributes, $a_{i j}=1 / a_{j i}$ and $a_{i j}=a_{i k} / a_{j k}$ indicate how much more important objective $i$ is than objective $j$ to the decision maker. The relative importance 
is measured by using a scale from 1 to 9 , where 1 represents that objective $i$ and $j$ are equally important, 3 represents that objective $i$ is just slightly more important than $j, 5$ represents objective $i$ is somewhat more important than $j, 7$ represents that objective $i$ is much more important than $j$, and 9 represents that objective $i$ is far more important than $j[53,79]$. We measure the relative importance by using the scale 1 to 5 in this study.

(3) determine the relative weights; as $a_{i j}$ approximates to $w_{i} / w_{j}$, i.e., $a_{i j} \cong w_{i} / w_{j}$, matrix A can be transformed as follows:

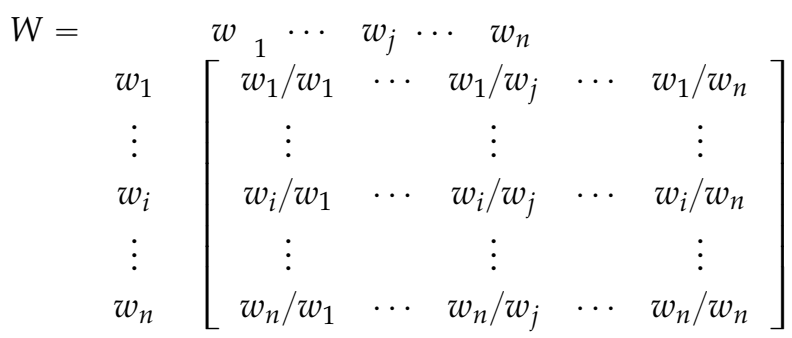

The relative weights are derived by addressing the eigenvector $w$ with the largest eigenvalue $\lambda_{\max }$ of matrix $\mathrm{A}$, which should satisfy the equation $A w=\lambda_{\max } w$. In addition, the consistency index C.I. and the consistency ratio C.R., as two examination indicators, should be calculated to ensure the accuracy of the relative weights and the consistency of the subjective decision. These are:

$$
\begin{gathered}
\text { C.I. }=\left(\lambda_{\max }-n\right) /(n-1) \\
\text { C.R. }=\text { C.I. } / \text { R.I. }
\end{gathered}
$$

where R.I. is a random consistency index which varies with the size of the matrices, e.g., 1.11 for a $5 \times 5$ matrix. C.I. should be less than 0.1 in order for a suitable result $[53,80]$.

\subsection{Grey Relational Analysis for Materials Evaluation}

GRA or grey incidence analysis, proposed by Professor Deng Julong in 1984, has been developed as a quantitative approach to aid decision-making by examining the degree of similarity or difference between two sequences based upon the grade of relation [50,81-83]. The more similar the two sequences are, the greater the grey relational correlation is, and vice versa [50,84].

To use GRA, it is necessary to normalize the data related to the sequence of selected criteria to a common scale for comparison. Basically, there are three approaches for normalization [50,51]:

(1) If the ideal value of sequence of selected criteria is preferred to be larger, such as indicators of sales profit, materials recyclability, or reusability, the consequence can be normalized as follows:

$$
\beta_{i}(k)=\frac{\beta_{i}(k)-\min \beta_{i}(k)}{\max \beta_{i}(k)-\min \beta_{i}(k)}
$$

where $\beta_{i}(k)$ is the comparable sequence of selected evaluation criteria.

(2) If the ideal value of sequence of selected criteria is preferred to be smaller, such as direct cost, manufacturing cost, or energy consumption, the consequence can be normalized as follows:

$$
\beta_{i}(k)=\frac{\max \beta_{i}(k)-\beta_{i}(k)}{\max \beta_{i}(k)-\min \beta_{i}(k)}
$$

where $\beta_{i}(k)$ is the comparable sequence of selected evaluation criteria.

(3) If the ideal value is determined within a numerical value range, the sequence can be normalized as follows:

$$
\beta_{i}(k)=1-\frac{\left|\beta_{i}(k)-\beta_{i}\right|}{\max \beta_{i}(k)-\beta_{i}}
$$


where $\beta_{i}(k)$ is the comparable sequence of selected evaluation criteria, and $\beta_{i}$ is the determined ideal value.

Following the above normalization, a grey relational coefficient is calculated. It demonstrates the relationship between the non-dimensional expected optimal sequence and the original sequence $[24,85]$. The grey relational coefficient is:

$$
\delta_{i}(k)=\frac{\operatorname{minmin}_{i}\left\|\beta_{0}(k)-\beta_{j}(k)\right\|+\underset{i}{\varepsilon \operatorname{maxmax}_{j}\left\|\beta_{0}(k)-\beta_{j}(k)\right\|}}{\left\|\beta_{0}(k)-\beta_{j}(k)\right\|+\varepsilon \operatorname{maxmax}_{j}\left\|\beta_{0}(k)-\beta_{j}(k)\right\|}
$$

where $\varepsilon$ is defined as the distinguishing coefficient and $\varepsilon \in(0,1)$. Generally, $\varepsilon$ is set to 0.5 for further calculation [84].

Thus, the degree of grey incidence can be expressed as:

$$
\gamma_{i}=\sum_{k=1}^{n} w_{k} \cdot \delta_{i}(k)
$$

where $w_{k}$ is the weighting value of the selected indicator $k$ derived from the AHP approach.

The degree of grey incidence indicates the relationship between the comparability sequence and the reference sequence $[83,86]$. The reference sequence represents the best performance that can be achieved by any among the comparability sequences. When $\gamma_{i}$ grows much bigger, the comparability sequence approaches the reference sequence. When $\gamma_{i}$ reaches the maximum value, a comparability sequence of the corresponding material obtains the highest degree of grey incidence, which means the alternative material is better than its counterparts. Moreover, the performance of all the alternative materials can be ranked in a sequence, from most optimal to least.

\section{A Case Example}

A case example is presented in this section to demonstrate the application of the proposed methodology of materials selection for plastic pipe design. The plastic pipes are widely used in the water supply system of Sichuan Province, China, especially for indoor hot and cold water supply. They are manufactured out of three alternative materials: poly(vinyl chloride) (PVC), polypropylene (PP) and polyethylene (PE). Here, the PVC is specified as un-plasticized PVC (uPVC), with a synthesis of $15 \%$ chlorinated polyethylene (CPE) and 75\% PVC, and PP as a polypropylene random (PPR), with 5\% $\mathrm{PE}$ and $95 \% \mathrm{PP}$.

The case example employs a set of weight values determined by the principal engineer of the investigated manufacturer and adjusted by the retrieval results of the selected indicators from the online Scirus scientific database in order to avoid subjective judgment in comparing their importance. Scirus.com is a comprehensive academic search engine with over 440 million scientific items, including published scientific papers, patents, web sources, courseware, and current research progress [87]. Based on the retrieval results of each indicator using "hits" as the measure of importance, the relative importance is ranked from 1 to 13, as shown in Figure 1.

The grey relational result will be compared with the actual material selection in the investigated manufacturer of plastic pipe to verify the proposed approach. Table 2 shows how the selected indicators for the three alternative materials are measured. 


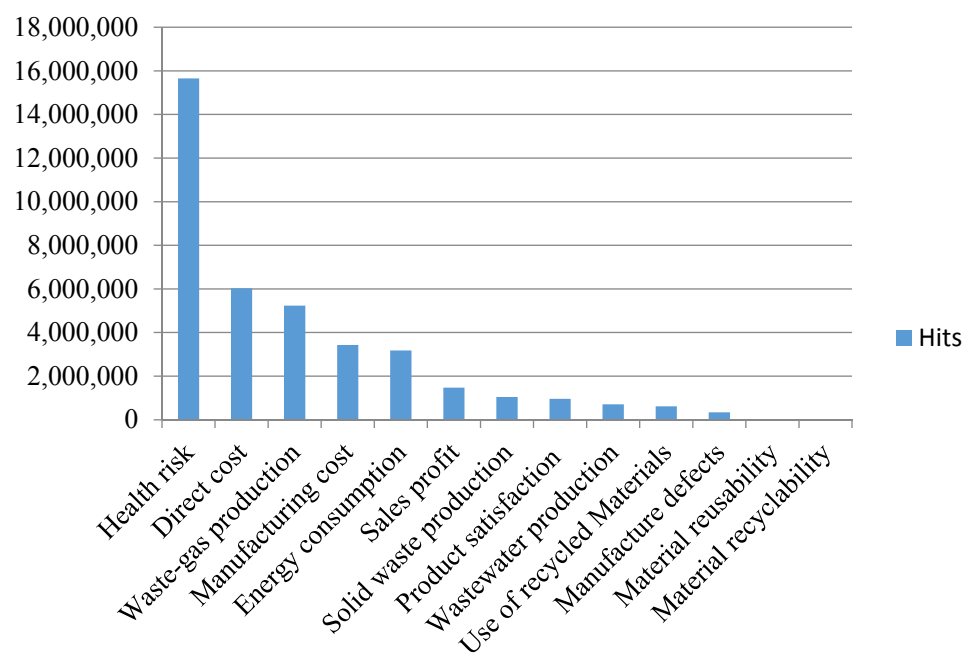

Figure 1. Rank of selected indicators as determined from Scirus.com retrieval.

Table 2. Measurements of the selected indicators.

\begin{tabular}{cc}
\hline Indicators & Measurements \\
\hline Direct cost & $p_{i}=\sum_{i=1}^{n} c_{i} / C$
\end{tabular}

where $p_{i}$ is the ratio of direct cost of the investigated pipe manufacturer, $c_{i}$ is the material cost corresponding to the $i$ th activity, e.g., $i=1$ denotes the purchasing cost of a specific material (PVC, PP, PE), $i=2$ denotes transportation cost of a specific material (PVC, PP, PE), $i=3$ denotes labor cost of a specific material (PVC, PP, PE), and $C$ is the total investment the investigated pipe manufacturer.

Manufacturing cost

$$
p_{m}=c_{m} / C
$$

where $p_{m}$ is the ratio of the investigated plastic pipe manufacturing cost, $c_{m}$ is the plastic pipe manufacturing cost of a specific material (PVC, PP, or PE), and $C$ is the total investment of the pipe manufacturer.

Manufacture defects

Sales profit

Energy consumption

$$
p_{d}=M_{d} / Q_{0}
$$

where $p_{d}$ is the ratio of the investigated plastic pipe manufacture defects, $M_{d}$ is the annual quantity of the manufacture defects of the investigated plastic pipe manufacturer, and $Q_{0}$ is the annual production of plastic pipes.

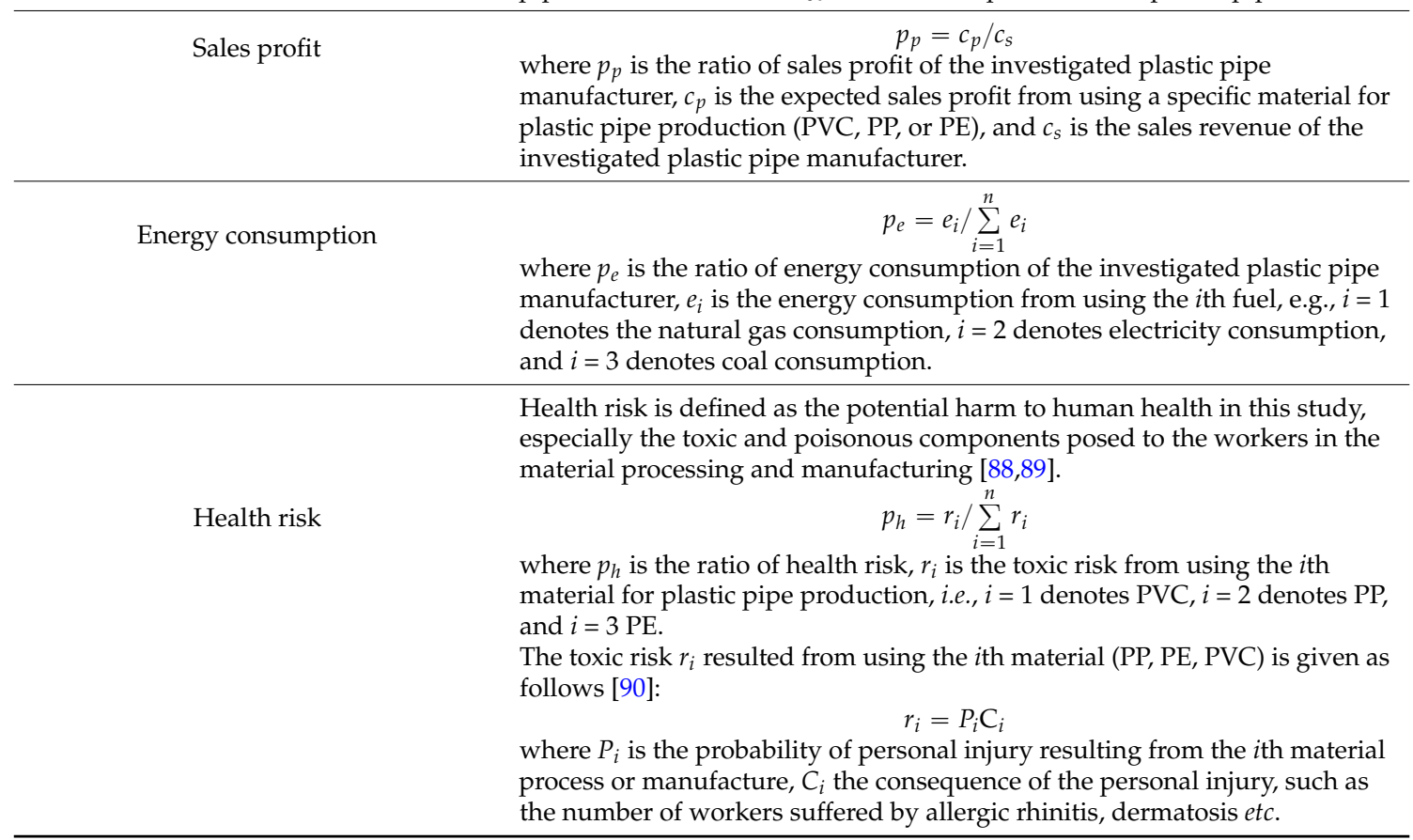


Table 2. Cont.

\begin{tabular}{|c|c|}
\hline Indicators & Measurements \\
\hline Waste-gas production & $\begin{array}{l}\qquad p_{g}=Q_{g} / Q_{o} \\
\text { where } p_{g} \text { is the ratio of waste-gas production of the investigated plastic pipe } \\
\text { manufacturer, } Q_{g} \text { is the annual emission of waste gas from using a specific } \\
\text { material for production ( PVC, PP, or PE), and } Q_{0} \text { is the annual production of } \\
\text { plastic pipes. }\end{array}$ \\
\hline Wastewater production & $\begin{array}{l}\qquad p_{w}=Q_{w} / Q_{\mathrm{o}} \\
\text { where } p_{w} \text { is the ratio of waste water production of the investigated plastic } \\
\text { pipe manufacturer, } Q_{w} \text { is the annual emission of waste water from using a } \\
\text { specific material for production (PVC, PP, or PE), and } Q_{0} \text { is the annual } \\
\text { production of plastic pipes. }\end{array}$ \\
\hline Solid waste production & $\begin{array}{l}\qquad P_{s}=Q_{s} / Q_{\mathrm{o}} \\
\text { where } p_{s} \text { is the ratio of solid waste production of the investigated plastic pipe } \\
\text { manufacturer, } Q_{w} \text { is the annual emission of solid waste from using a specific } \\
\text { material for production (PVC, PP, or PE), and } Q_{0} \text { is the annual production of } \\
\text { plastic pipes. }\end{array}$ \\
\hline Product satisfaction & $\begin{array}{l}p_{z} \\
\text { defined as the market share of plastic pipes while using a specific material } \\
\text { (PVC, PP, or PE), which is based upon the market of the downstream } \\
\text { distribution centers. }\end{array}$ \\
\hline Material recyclability & $\begin{array}{l}\text { Material recyclability is the extent to which waste materials can be converted } \\
\text { into reusable material, which are used to make new items, given } \\
\text { as follows [91]: } \\
\qquad p_{r}=Q_{r} / Q \\
\text { where } Q_{r} \text { is the theoretical quantity of recycled materials (PVC, PP, or PE), } \\
\text { and } Q \text { is the total quantity of waste materials produced of the investigated } \\
\text { plastic pipe manufacturer. }\end{array}$ \\
\hline Material reusability & $\begin{array}{l}\text { Material reusability is defined as the extent to which the material can be } \\
\text { reused directly in continuous cycles without losing their integrity or quality, } \\
\text { which is given as follows [92]: } \\
\qquad p_{R}=Q_{R} / Q \\
\text { where } Q_{R} \text { is the theoretical quantity of reused materials (PVC, PP, or PE), and } \\
Q \text { is the total quantity of waste materials produced of the investigated plastic } \\
\text { pipe manufacturer. }\end{array}$ \\
\hline Use of recycled Materials & $\begin{array}{l}\qquad p_{t}=Q^{\prime} / Q_{r} \\
\text { where } Q^{\prime} \text { is the actual recycled materials (PVC, PP, or PE), and } Q_{r} \text { is the } \\
\text { theoretical quantity of recycled materials of the investigated plastic pipe } \\
\text { manufacturer. }\end{array}$ \\
\hline
\end{tabular}

The data for the selected indicators are derived from a feasibility study report of a plastic pipe manufacturer, located in Leshan City, Sichuan Province, China. According to the measurements, the data have been processed dimensionlessly by percentage for further application of GRA, as shown in Table 3.

Table 3. Processed data of the selected indicators.

\begin{tabular}{cccc}
\hline \multirow{2}{*}{ Indicators } & \multicolumn{3}{c}{ Alternative Materials } \\
\cline { 2 - 4 } & PE & PP & PVC \\
\hline Direct cost & 95.5 & 90.3 & 90.0 \\
Manufacturing cost & 1.43 & 1.40 & 10.00 \\
Manufacture defects & 1.5 & 2.0 & 2.0 \\
Sales profit & 29.4 & 20.0 & 38.2 \\
Energy consumption & 92.5 & 99.6 & 39.7 \\
Health risk & 0 & 0 & 0.00084 \\
Waste-gas production & 0.006 & 1.130 & 0.230 \\
Wastewater production & 11.0 & 150.0 & 45.5 \\
Solid waste production & 0.09 & 50.00 & 0.54 \\
Product satisfaction & 25 & 10 & 55 \\
Material recyclability & 94.50 & 0.28 & 65.90 \\
Material reusability & 30.7 & 2.5 & 16.5 \\
Use of recycled Materials & 100 & 100 & 98 \\
\hline
\end{tabular}




\section{Results and Discussion}

Based upon the relative importance ranking list, the weighting value is calculated by the AHP method, as shown in Table 4. In order to simplify the computation, both AHP and GRA have been embodied into a compiled mathematical program implemented by MATLAB 2010. The degree of grey incidence $\gamma_{i}$ of the PVC, PP, and PE is calculated as $0.800457709,0.634945104$, and 0.604756842 , respectively. Different evaluated alternatives can be ranked in a sequence from the highest to the lowest grade. For instance, the ranking of degrees of grey incidence is deemed as the order of superiority for each material in this study. The assessed alternative material corresponding to the maximum grey correlative degree is deemed as the optimal material, and vice versa. Thus, $\gamma_{P V C}>\gamma_{P P}>\gamma_{P E}$ is obtained, which shows that the PVC is the optimum alternative material and PE is the least optimal choice.

Table 4. Weighting value of the selected indicators based on the Scirus.com retrieval results.

\begin{tabular}{cc}
\hline Indicators & Weighting Value \\
\hline Direct cost & 0.155623917 \\
Manufacturing cost & 0.088494826 \\
Manufacture defects & 0.008907485 \\
Sales profit & 0.038003123 \\
Energy consumption & 0.082127819 \\
Health risk & 0.404081921 \\
Waste-gas production & 0.135173217 \\
Wastewater production & 0.018335576 \\
Solid waste production & 0.027011282 \\
Product satisfaction & 0.024883922 \\
Material recyclability & 0.000545566 \\
Material reusability & 0.000975515 \\
Use of recycled Materials & 0.015835831 \\
\hline
\end{tabular}

From Table 4, it is clear that the indicator "health risk" accounts for about $40 \%$ of the weightings. This is because the manufacturer's employees are likely exposed to toxic substances when PVC materials are processed [93]. However, PVC has the highest sales profit and market share (product satisfaction), along with the lowest proportion of direct cost and energy consumption. That is why PVC exhibits the best overall performance among the three alternative materials, even if its inherent health risk is higher than PP or PE. Similarly, PP's degree of grey incidence is higher than PE, although PE material is superior to PP based on most of the data for the selected indicators. This is because PP shows better performance in both direct cost and manufacturing cost, which accounts for a large proportion of the relative importance. This shows that the weighting value may play a critical role in the sensitivity of the grey relational model in this case study.

In the real world, a manufacturer may define profits as the main criterion of business success, while placing little emphasis on life-cycle environmental impact of its products [94,95]. Accordingly, the selection of materials is strongly influenced by market demand, cost-benefit analysis, materials properties, and fashion and popularity, as the fundamental drivers of design [24]. For instance, the investigated manufacturer in this study was originally cost-oriented in material selection, and PVC was used for plastic pipe manufacturing. This verifies the evaluation results of the integrated MADM approach. However, a sustainable business should focus on both economic prosperity, environmental and social performances [96,97]. In green design, the weighting assignment for materials selection should pay closer attention to the environmental and social perspectives. This could be expressed by increased weighting values for materials recyclability and reusability to enhance the sustainability of products.

This integrated MADM approach is flexible, which can provide a comprehensive matrix to judge a range of alternative materials, including index of environmental impact, economic perspective, etc. 
For instance, a similar study can be found by Zhao et al. (2012), who has employed "binary-dominance matrix" with GRA to aid decision-making on materials selection while taking environmental evaluation into account. Five PVC materials with close properties have been subjected to environmental evaluation to determine their environmentally friendliness for handbag manufacture [24]. Furthermore, Kumar et al. (2014) have offered a MCDM approach in which criteria importance was computed by entropy method, and the alternative materials were ranked by using the TOPSIS method [18]. Wang et al. (2015) have employed AHP combined with GRA to select a biomass briquette fuel-system scheme based on a variety of evaluation criteria, such as economy, cleanness and environment protection, production capacity, product quality and production stability [52]. Yang et al. (2015) have focused on the materials selection from remanufacturing perspective and developed a MCDM model by using the Fuzzy TOPSIS approach to evaluate the performance of the alternative automotive materials [98]. These similar studies have reflected the extension and validity of the proposed method.

However, the weightings play a critical role to affect the sensitivity of the GRA, which is subject to the preference of the indicators. AHP is a subjective weighting approach, depending upon the judgment and synthesis of decision makers $[99,100]$. It may be replaced by the objective weighting methods, such as the Entropy method, TOPSIS, etc., in which the weights are derived from the collected data corresponding to each indicator. Thus, the influence of weighting variation on materials selection can be investigated to identify the sensitivity of the integrated approach.

\section{Conclusions}

This paper introduces a computational approach for materials selection in the context of green design by using GRA, integrated with AHP. A set of selected indicators is determined using the principles of green design, while the AHP method is used to examine the relative importance and assign the corresponding weighting values for each indicator. Moreover, GRA is applied to rank the alternative materials based upon the multiple attributes of their performances. In order to demonstrate how to use the computational approach, a case example is provided. Three materials, PVC, PP, and PE, are investigated to determine their best economic, environmental, and social performances for plastic pipe design. With the weighting value for the selected criteria being determined by the principal engineer of the investigated manufacturer and adjusted by keyword retrieval from the Scirus database, PVC is determined as the optimal material, and PE the least optimal.

However, limitations of this computational approach still remain. Although the selected criteria are generic and may be easily extended to various applications, whether these indicators can be used to fully cover the three dimensions of sustainability, namely, the economic, environmental, and social dimensions, still requires further investigation. Second, the weighting determination should be re-adjusted by taking the engineering designer's preferences into account, while giving full priority to environmental and social considerations. This approach is expected to be applied to more case scenarios in order to examine and refine its validity and sensitivity in the future.

Acknowledgments: This study is sponsored by National Natural Science Foundation of China (No. 41301639; No. 41571520; No. 41461118), Sichuan Provincial Key Technology Support (No. 2014GZ0168), and Innovative Research Team of Ministry of Education of China (No. IRT13092).

Author Contributions: Rui Zhao was involved in conceptualizing the whole study, proposing the integrated MADM model for material selection and writing the whole paper. Han Su implemented the calculation of the MADM model. Xiaolang Chen conducted the case study to collect the data and verify the proposed model. Yanni Yu improved the whole structure of the paper.

Conflicts of Interest: The authors declare no conflict of interest.

\section{References}

1. Brezet, H.; van Hemel, C. Eco-Design: A Promising Approach to Sustainable Production and Consumption; UNEP and TU Delft: Delft, The Netherlands, 1997. 
2. Fiksel, J. Design for Environment: A Guide to Sustainable Product Development; McGraw-Hill: New York, NY, USA, 2009.

3. Bevilacqua, M.; Ciarapica, F.E.; Giacchetta, G. Eco-Design: A Promising Approach to Sustainable Production and Consumption; Springer: London, UK, 2011.

4. Ray, D.L.; Guzzo, L. Environmental Overkill: Whatever Happened to Common Sense; Harper Collins: New York, NY, USA, 1993.

5. McLennan, J.F. The Philosophy of Sustainable Design; Ecotone LLC: Kansas City, MO, USA, 2004.

6. Aoe, T. Eco-efficiency and eco design in electrical and electronic products. J. Clean. Prod. 2007, 15, 1406-1414. [CrossRef]

7. Clark, G.; Kosoris, J.; Hong, L.N.; Crul, M. Design for Sustainability: Current Trends in Sustainable Product Design and Development. Sustainability 2009, 1, 409-424. [CrossRef]

8. He, B.; Huang, S.; Wang, J. Product Low-Carbon Design Using Dynamic Programming Algorithm. Int. J. Precis. Eng. Manuf.-Green Technol. 2015, 2, 37-42. [CrossRef]

9. Ashby, M.F.; Johnson, K. Materials and Design: The Art and Science of Material Selection in Product Design; Butterworth-Heinemann: Oxford, UK, 2013.

10. Chauhan, A.; Vaish, R. Magnetic material selection using multiple attribute decision-making approach. Mater. Des. 2012, 36, 1-5. [CrossRef]

11. Khare, S.; Dell'Amico, M.; Knight, C.; McGarry, S. Selection of materials for high temperature latent heat energy storage. Sol. Energy Mater. Sol. Cells 2012, 107, 20-27. [CrossRef]

12. Mansor, M.R.; Sapuan, S.M.; Zainudin, E.S.; Nuraini, A.A.; Hambali, A. Hybrid natural and glass fibers reinforced polymer composites material selection using Analytical Hierarchy Process for automotive brake lever design. Mater. Des. 2013, 51, 484-492. [CrossRef]

13. O'Connor, T.F.; Zaretski, A.V.; Savagatrup, S.; Printz, A.D.; Wilkes, C.D.; Diaz, M.I.; Lipomi, D.J. Wearable organic solar cells with high cyclic bending stability: Materials selection criteria. Sol. Energy Mater. Sol. Cells 2016, 144, 438-444. [CrossRef]

14. Prasad, K.; Chakraborty, S. A quality function deployment-based model for material selection. Mater. Des. 2013, 49, 525-535. [CrossRef]

15. Tamani, N.; Mosse, P.; Croitoru, M.; Buche, P.; Guillard, V.; Guillaume, C.; Gontard, N. An argumentation system for eco-efficient packaging material selection. Comput. Electron. Agric. 2015, 113, 174-192. [CrossRef]

16. Kwong, C.K.; Jiang, H.; Luo, X.G. AI-based methodology of integrating affective design, engineering, and marketing for defining design specifications of new products. Eng. Appl. Artif. Intell. 2016, 47, 49-60. [CrossRef]

17. Rahman, S.; Odeyinka, H.; Perera, S.; Bi, Y. Product-cost modelling approach for the development of a decision support system for optimal roofing material selection. Expert Syst. Appl. 2012, 39, 6857-6871. [CrossRef]

18. Kumar, R.; Jagadish; Ray, A. Selection of Material for Optimal Design Using Multi-Criteria Decision Making. Procedia Mater. Sci. 2014, 6, 590-596. [CrossRef]

19. IIg, P.; Hoehne, C.; Guenther, E. High-performance materials in infrastructure: A review of applied life cycle costing and its drivers-The case of fiber-reinforced composites. J. Clean. Prod. 2016, 112, 926-945.

20. Tseng, K.C.; Lin, B.; Han, C.M. An Intelligent System for Sustainable Product Design at the Concept Development Stage. Comput. Aided Des. Appl. 2012, 9, 397-408. [CrossRef]

21. Riberto, I.; Peças, P.; Henriques, E. A Life Cycle Framework to Support Materials Selection for Eco Design: A Case Study on Biodegradable Polymers. Mater. Des. 2013, 51, 300-308. [CrossRef]

22. Gerstlberger, W.; Knudsen, M.P.; Stampe, I. Sustainable Development Strategies for Product Innovation and Energy Efficiency. Bus. Strategy Environ. 2014, 23, 131-144. [CrossRef]

23. Beng, L.G.; Omar, B. Integrating Axiomatic Design Principles into Sustainable Product Development. Int. J. Precis. Eng. Manuf.-Green Technol. 2014, 1, 107-117. [CrossRef]

24. Zhao, R.; Neighbour, G.; Deutz, P.; McGuire, M. Materials Selection for Cleaner Production: An Environmental Evaluation Approach. Mater. Des. 2012, 37, 429-434. [CrossRef]

25. Umezawa, O.; Shinohara, Y.; Halada, K. New Aspects of Ecomaterials from the Viewpoints of the Consumer and Regional Communities. Mater. Trans. 2014, 55, 745-749. [CrossRef]

26. Giudice, F.; la Rosa, G.; Risitano, A. Materials selection in the life-cycle design process: A method to integrate mechanical and environmental performances in optimal choice. Mater. Des. 2005, 26, 9-20. [CrossRef] 
27. Bribián, I.Z.; Capilla, A.V.; Usón, A.A. Life cycle assessment of building materials: Comparative analysis of energy and environmental impacts and evaluation of the eco-efficiency improvement potential. Build. Environ. 2011, 46, 1133-1140. [CrossRef]

28. Chan, H.K.; Wang, X.; Raffoni, A. An integrated approach for green design: Life-cycle, fuzzy AHP and environmental management accounting. Br. Account. Rev. 2014, 46, 344-360. [CrossRef]

29. Pereira, L.; Mafalda, R.; Marconcini, J.M.; Mantovani, G.L. The Use of Sugarcane Bagasse-Based Green Materials for Sustainable Packaging Design. In ICoRD'15-Research into Design Across Boundaries; Chakrabarti, Ed.; Springer: London, UK, 2014; Volume 2, pp. 113-123.

30. Ribeiro, I.; Peças, P.; Henriques, E. A life cycle framework to support material selection for Ecodesign: A case study on biodegradable polymers. Mater. Des. 2013, 51, 300-308. [CrossRef]

31. Hosseinijou, S.A.; Mansour, S.; Shirazi, M.A. Social life cycle assessment for material selection: A case study of building materials. Int. J. Life Cycle Assess. 2014, 19, 620-645. [CrossRef]

32. Van der Velden, N.M.; Kuusk, K.; Köhler, A.R. Life cycle assessment and eco-design of smart textiles: The importance of material selection demonstrated through e-textile product redesign. Mater. Des. 2015, 84, 313-324. [CrossRef]

33. Caputo, J.; Balogh, S.B.; Volk, T.A.; Johnson, L.; Puettmann, M.; Lippke, B.; Oneil, E. Incorporating uncertainty into a life cycle assessment (LCA) model of short-rotation willow biomass (Salix spp.) crops. BioEnergy Res. 2014, 7, 48-59. [CrossRef]

34. Chen, X.; Corson, M.S. Influence of emission-factor uncertainty and farm-characteristic variability in LCA estimates of environmental impacts of French dairy farms. J. Clean. Prod. 2014, 81, 150-157. [CrossRef]

35. Van Kesteren, I.E.H. Product Designers' Information Needs in Materials Selection. Mater. Des. 2008, 29, 133-145. [CrossRef]

36. Ashby, M.F.; Shercliff, H.; Cebon, D. Materials: Engineering, Science, Processing and Design; Butterworth-Heinemann: Oxford, UK, 2013.

37. Rao, R.V.; Patel, B.K. A subjective and objective integrated multiple attribute decision-making method for material selection. Mater. Des. 2010, 31, 4738-4747. [CrossRef]

38. Huang, H.H.; Zhang, L.; Liu, Z.F.; Sutherland, J.W. Multi-Criteria Decision Making and Uncertainty Analysis for Materials Selection in Environmentally Conscious Design. Int. J. Adv. Manuf. Technol. 2011, 52, 421-432. [CrossRef]

39. Athawale, V.M.; Chakraborty, S. Material Selection Using Multi-Criteria Decision-Making Methods: A Comparative Study. Proc. Insist. Mech. L 2012, 226, 266-285. [CrossRef]

40. Jahan, A.; Edwards, K.L. Multi-Criteria Decision Analysis for Supporting the Selection of Engineering Materials in Product Design; Butterworth-Heinemann: Oxford, UK, 2013.

41. Zhou, C.C.; Yin, G.F.; Hu, X.B. Multi-Objective Optimization of Material Selection for Sustainable Products: Artificial Neural Networks and Genetic Algorithm Approach. Mater. Des. 2009, 30, 1209-1215. [CrossRef]

42. Chauhan, A.; Vaish, R. Hard Coating Material Selection Using Multi-Criteria Decision Making. Mater. Des. 2013, 44, 240-245. [CrossRef]

43. Karande, P.; Chakraborty, S. Application of Multi-Objective Optimization on the Basis of Ratio Analysis (MOORA) Method for Materials Selection. Mater. Des. 2012, 37, 317-324. [CrossRef]

44. Zander, J.; Sandström, R. Materials Selection with Several Sizing Variables Taking Environmental Impact into Account. Mater. Des. 2012, 37, 243-250. [CrossRef]

45. Jahan, A.; Mustapha, F.; Ismail, M.Y.; Sapuan, S.M.; Bahraminasab, M. A Comprehensive VIKOR Method for Materials Selection. Mater. Des. 2011, 32, 1215-1221. [CrossRef]

46. Girubha, R.J.; Vinodh, S. Application of Fuzzy VIKOR and Environmental Impact Analysis for Materials Selection of an Automobile Component. Mater. Des. 2012, 37, 478-486. [CrossRef]

47. Jahan, A.; Barhraminasab, M.; Edwards, K.L. A Target-Based Normalization Technique for Materials Selection. Mater. Des. 2012, 35, 647-654. [CrossRef]

48. Caliskan, H.; Kursuncu, B.; Kurbanoglu, C.; Guven, S.Y. Material Selection for the Tool Holder Working under Hard Milling Conditions Using Different Multi Criteria Decision Making Methods. Mater. Des. 2013, 45, 473-479. [CrossRef]

49. Chan, J.W.K.; Tong, T.K.L. Multi-Criteria Material Selections and End-of-Life Product Strategy: Grey Relational Analysis Approach. Mater. Des. 2007, 28, 1539-1546. [CrossRef] 
50. Deng, J.L. The Essential Methods of Grey Systems; Huazhong University of Science and Technology Press: Wuhan, China, 1992. (In Chinese)

51. Wei, G. Grey relational analysis model for dynamic hybrid multiple attribute decision-making. Knowl.-Based Syst. 2011, 24, 672-679. [CrossRef]

52. Wang, Z.; Lei, T.; Chang, X.; Shi, X.; Xiao, J.; Li, Z.; Yang, S. Optimization of a biomass briquette fuel system based on grey relational analysis and analytic hierarchy process: A study using cornstalks in China. Appl. Energy 2015. [CrossRef]

53. Saaty, T.L. Analytic hierarchy process. In Encyclopedia of Operations Research and Management Science; Harris, G., Ed.; Springer: London, UK, 2001; pp. 19-28.

54. Xu, G.; Yang, Y.P.; Lu, S.Y.; Li, L.; Song, X. Comprehensive evaluation of coal-fired power plants based on grey relational analysis and analytic hierarchy process. Energy Policy 2011, 39, 2343-2351. [CrossRef]

55. Vezzoli, C.; Manzini, E. Design for Environmental Sustainability; Springer: London, UK, 2008.

56. Dornfeld, D.A. Moving towards Green and Sustainable Manufacturing. Int. J. Precis. Eng. Manuf.-Green Technol. 2014, 1, 63-66. [CrossRef]

57. Stewart, W.H., Jr.; Carland, J.C.; Carland, J.W.; Watson, W.W.; Sweo, R. Entrepreneurial dispositions and goal orientations: A comparative exploration of United States and Russian entrepreneurs. J. Small Bus. Manag. 2003, 41, 27-46. [CrossRef]

58. Smith, P. The Relationship between Management Accounting, Profitability and Operations in an Uncertain World: Evidence from Literature and Practice. Ph.D. Thesis, Cranfield University, Cranfield, UK, 2007.

59. Kane, G. The Three Secrets of Green Business: Unlocking Competitive Advantage in a Low Carbon Economy; Earthscan: London, UK, 2010.

60. Wang, H.F.; Gupta, S.M. Green Supply Chain Management: Product Life Cycle Approach; McGraw-Hill: New York, NY, USA, 2011.

61. Amah, E. Corporate Culture and Organizational Effectiveness: A Study of the Nigerian Banking Industry. Eur. J. Bus. Manag. 2012, 4, 212-229.

62. Zhao, R.; Peng, D.; Li, Y. An Interaction between Government and Manufacturer in Implementation of Cleaner Production: A Multi-Stage Game Theoretical Analysis. Int. J. Environ. Res. 2015, 9, 1069-1078.

63. Mezher, T.; Ajam, M. Integrating Quality, Environmental and Supply Chain Management Systems into the Learning Organisation. In Greening the Supply Chain; Sarkis, Ed.; Springer: London, UK, 2006; pp. 67-85.

64. Gummesson, E. Commentary on "The role of innovation in driving the economy: Lessons from the global financial crisis". J. Bus. Res. 2014, 67, 2743-2750. [CrossRef]

65. Dubey, R.; Gunasekaran, A.; Ali, S.S. Exploring the relationship between leadership, operational practices, institutional pressures and environmental performance: A framework for green supply chain. Int. J. Prod. Econ. 2015, 160, 120-132. [CrossRef]

66. Testa, F.; Iraldo, F. Shadows and lights of GSCM (green supply chain management): Determinants and effects of these practices based on a multinational study. J. Clean. Prod. 2010, 18, 953-962. [CrossRef]

67. Madanhire, I.; Mugwindiri, K.; Mbohwa, C. Enhancing cleaner production application in fertilizer manufacturing: Case study. Clean. Technol. Environ. 2015, 17, 667-679. [CrossRef]

68. Ljungberg, L.Y. Materials selection and design for development of sustainable products. Mater. Des. 2007, 28, 466-479. [CrossRef]

69. Serafini, M.; Russo, D.; Rizzi, C. Multi Criteria Material Selection for Eco-Design. Comput. Aided Des. Appl. 2015, 12, 526-536. [CrossRef]

70. Binhussain, M.A.; Marangoni, M.; Bernardo, E.; Colombo, P. Sintered and glazed glass-ceramics from natural and waste raw materials. Ceram. Int. 2014, 40, 3543-3551. [CrossRef]

71. Akadiri, P.O.; Olomolaiye, P.O.; Chinyio, E.A. Multi-criteria evaluation model for the selection of sustainable materials for building projects. Autom. Constr. 2013, 30, 113-125. [CrossRef]

72. Piccinno, F.; Hischier, R.; Saba, A.; Mitrano, D.; Seeger, S.; Som, C. Multi-perspective application selection: A method to identify sustainable applications for new materials using the example of cellulose nanofiber reinforced composites. J. Clean. Prod. 2016, 112, 1199-1210. [CrossRef]

73. William, M.; McDonough, W. Cradle to Cradle: Remaking the Way We Make Things; North Point Press: New York, NY, USA, 2002.

74. Bjørn, A.; Hauschild, M.Z. Absolute versus relative environmental sustainability. J. Ind. Ecol. 2013, 17, 321-332. [CrossRef] 
75. Figge, F.; Hahn, T. Sustainable value added-Measuring corporate contributions to sustainability beyond eco-efficiency. Ecol. Econ. 2004, 48, 173-187. [CrossRef]

76. Roscoe, S.; Cousins, P.D.; Lamming, R.C. Developing eco-innovations: A three-stage typology of supply networks. J. Clean. Prod. 2016, 122, 1948-1959. Available online: http://doi:10.1016/j.jclepro.2015.06.125 (accessed on 11 January 2016). [CrossRef]

77. Lo, T.P.; Guo, S.J. Effective weighting model based on the maximum deviation with uncertain information. Expert Syst. Appl. 2010, 37, 8445-8449. [CrossRef]

78. Alemi-Ardakani, M.; Milani, A.S.; Yannacopoulos, S.; Shokouhi, G. On the effect of subjective, objective and combinative weighting in multiple criteria decision-making: A case study on impact optimization of composites. Expert Syst. Appl. 2016, 46, 426-438. [CrossRef]

79. Winston, W.L.; Albright, S.C. Practical Management Science; South-Western Cengage Learning: Boston, MA, USA, 2008.

80. Tzeng, G.H.; Huang, J.J. Multiple Attribute Decision Making: Methods and Applications; CRC Press: Boca Raton, FL, USA, 2011.

81. Deng, J.L. Introduction of Grey System. J. Grey Syst. 1989, 1, 1-24.

82. Liu, S.F.; Lin, Y. Grey Information: Theory and Practical Application; Springer: London, UK, 2006.

83. Tzeng, M.L. Using Linguistic Preferences and Grey Relational Analysis to Evaluate the Environmental Knowledge Management Capacity. Expert Syst. Appl. 2010, 37, 70-81. [CrossRef]

84. Liu, S.F.; Lin, Y. Grey Systems: Theory and Application; Springer: London, UK, 2010.

85. Khan, Z.A.; Kamaruddin, S.; Siddiquee, A.N. Feasibility Study of Use of Recycled High Density Polyethylene and Multi Response Optimization of Injection Moulding Parameters using Combined Grey Relational and Principal Component Analyses. Mater. Des. 2010, 31, 2925-2931. [CrossRef]

86. Lee, W.S.; Lin, Y.C. Evaluating and Ranking Energy Performance of Office Buildings Using Grey Relational Analysis. Energy 2011, 36, 2551-2556. [CrossRef]

87. Zhao, R. Environmental Risk Management System Design for Hazardous Waste Materials. Ph.D. Thesis, University of Hull, Hull, UK, 2012.

88. Li, Z.; Ma, Z.; van der Kuijp, T.J.; Yuan, Z.; Huang, L. A review of soil heavy metal pollution from mines in China: Pollution and health risk assessment. Sci. Total Environ. 2014, 468, 843-853. [CrossRef] [PubMed]

89. Wang, Y.; Hu, J.; Lin, W.; Wang, N.; Li, C.; Luo, P.; Liu, Y. Health risk assessment of migrant workers' exposure to polychlorinated biphenyls in air and dust in an e-waste recycling area in China: Indication for a new wealth gap in environmental rights. Environ. Int. 2016, 87, 33-41. [CrossRef] [PubMed]

90. Sundblad, E.L.; Biel, A.; Gärling, T. Intention to change activities that reduce carbon dioxide emissions related to worry about global climate change consequences. Eur. Rev. Appl. Psychol. 2014, 64, 13-17. [CrossRef]

91. Cimpan, C.; Rothmann, M.; Hamelin, L.; Wenzel, H. Towards increased recycling of household waste: Documenting cascading effects and material efficiency of commingled recyclables and biowaste collection. J. Environ. Manag. 2015, 157, 69-83. [CrossRef] [PubMed]

92. Su, B.; Heshmati, A.; Geng, Y.; Yu, X. A review of the circular economy in China: Moving from rhetoric to implementation. J. Clean. Prod. 2013, 42, 215-227. [CrossRef]

93. Fong, J.P.; Lee, F.J.; Lu, I.S.; Uang, S.N.; Lee, C.C. Estimating the Contribution of Inhalation Exposure to Di-2-Ethylhexyl Phthalate (DEHP) for PVC Production Workers, Using Personal Air Sampling and Urinary Metabolite Monitoring. Int. J. Hyg. Environ. Health 2014, 217, 102-109. [CrossRef] [PubMed]

94. Deutz, P.; Neighbour, G.; McGuire, M. Integrating Sustainable Waste Management into Product Design: Sustainability as a Functional Requirement. Sustain. Dev. 2010, 18, 229-239. [CrossRef]

95. Zhao, R.; Neighbour, G.; McGuire, M.; Deutz, P. A Software Based Simulation for Cleaner Production: A Game between Manufacturers and Government. J. Loss Prev. Process Ind. 2013, 26, 59-67. [CrossRef]

96. Savitz, A.W.; Weber, K. The Triple Bottom Line: How Today's Best-Run Companies Are Achieving Economic, Social and Environmental Success and How You Can too; Jossey-Bass: San Francisco, FL, USA, 2006.

97. Pardo, R.J.H.; Bhamra, T.; Bhamra, R. Sustainable Product Service Systems in Small and Medium Enterprises (SMEs): Opportunities in the Leather Manufacturing Industry. Sustainability 2012, 4, 175-192. [CrossRef]

98. Yang, S.S.; Nasr, N.; Ong, S.K.; Nee, A.Y.C. Designing automotive products for remanufacturing from material selection perspective. J. Clean. Prod. 2015. [CrossRef] 
99. Tjader, Y.; May, J.H.; Shang, J.; Vargas, L.G.; Gao, N. Firm-level outsourcing decision-making: A balanced scorecard-based analytic network process model. Int. J. Prod. Econ. 2014, 147, 614-623. [CrossRef]

100. Arce, M.E.; Saavedra, Á.; Míguez, J.L.; Granada, E. The use of grey-based methods in multi-criteria decision analysis for the evaluation of sustainable energy systems: A review. Renew. Sustain. Energy Rev. 2015, 47, 924-932. [CrossRef]

(c)

(C) 2016 by the authors; licensee MDPI, Basel, Switzerland. This article is an open access article distributed under the terms and conditions of the Creative Commons by Attribution (CC-BY) license (http:/ / creativecommons.org/licenses/by/4.0/). 